\title{
Periodontal Health Status and Microbiological Analysis of Orthodontic Patient in Dhaka Bangladesh
}

\author{
${ }^{1}$ Sabnam K BDS, MSc, ${ }^{2}$ Mamun MSA BDS, FCPS, ${ }^{3}$ Mahmud A PhD and ${ }^{4}$ Haque S BDS, MS
}

\begin{abstract}
Aim: The aim of the study was to determine the level of bacteria in dental plaque associated with fixed orthodontic appliances.

Materials and Methods: This longitudinal observational study was done during April'2014 to September'2014 in the Department of Microbiology, Primeasia University, Banani, Dhaka. The 100 samples were collected purposively from the Department of Orthodontics, University Dental College and Hospital, Dhaka and reported private Orthodontic clinic of Bangladesh. The microbiological test was done in the Department of Microbiology, Primeasia University, Banani, Dhaka.

Results: The study result showed, there were significantly increased plaque accumulation as well as microorganisms in patient who wear fixed orthodontic appliances than normal subjects. Most of the organisms were streptococcus and most organisms were sensitive to antibiotic except eromycin, sensitive to paste (triclosan and fluoride) but resistant to mouth wash.
\end{abstract}

Conclusion:The components of fixed appliance can hamper proper oral hygiene maintenance increases the chance of accumulation of plaque that lead to caries. So appropriate tooth brush with proper paste can inhibit microbial colonization on tooth surfaces.

Key Words: Orthodontic appliance ; Microbiological analysis; Periodontal health

\section{INTRODUCTION}

Orthodontics is concerned with correcting or improving the position of teeth and correcting any malocclusion. Day by day, the popularity of Orthodontic treatment is increasing in the world as well as in Bangladesh. Most of the orthodontic cases are noninvasive and health risk is low. ${ }^{1}$ However, these appliances can be associated to difficulty in cleaning and serve as different impact zones and modify microbial adherence and colonization, acting as foreign reserves and possible sources of infection. ${ }^{2,3}$ Good oral hygiene maintenance, such as adequate tooth brushing, mouth rinsing and dental flossing, plays a vital role in maintaining healthy teeth, especially in the orthodontic patients. ${ }^{4,5}$ The placement of fixed orthodontic appliances generally impede good oral hygiene, and the appliance component can cause alteration in oral micro flora by reducing $\mathrm{pH}$, increasing affinity of bacteria to the metallic surface because of electrostatic reactions, and causing retention areas for microorganisms. Thus, they lead to plaque accumulation around the bracket base. Plaque retention surrounding orthodontic appliances leads to enamel demineralization caused by organic acids produced by bacteria in the dental plaque. ${ }^{5-9}$

Plaque is tenaciously adherent deposit that forms on tooth surfaces. It consists of an organic matrix containing dense concentration of bacteria. In microbiological terms, plaque is a biofilm. Biofilms consist of a hydrated viscous phase formed from bacteria and their extracellular polysaccharide matrices. Plaques become visible, particularly on the labial surfaces of the incisors, when tooth brushing stopped for 12 -24 hours. $^{10}$

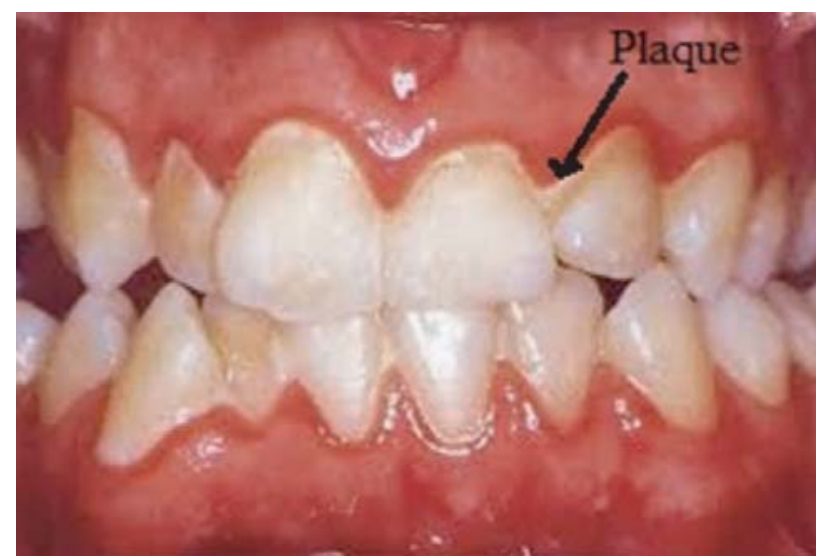

Figure 1: Dental Plaque

Fixed orthodontic appliances create new retention areas, which are suitable for bacterial colonization and lead to an the absolute number and percentage of Streptococcus mutans and lactobacilli. ${ }^{4,11,12}$ Forsberg et al. ${ }^{11}$ evaluated microbial colonization of 12 patients treated by fixed orthodontic

${ }^{1}$ Dr. Kohinoor Sabnam BDS, MSc (Micro), Dental Surgeon, Mamun’s Ortho Dental, Moghbazar Dhaka. ${ }^{2}$ Dr. Mohammad Shamim Al Mamun BDS, FCPS (ortho), Assoc. Prof. and Head, Dept. of Orthodontics, University Dental College and Hospital, Moghbazar, Dhaka. ${ }^{3}$ Dr. Asif Mahmud PhD, Asst. Prof. Dept. of Microbiology, Primeasia University, Banani Dhaka and ${ }^{4}$ Dr. Sabrina Haque BDS, MS, Assoc. Prof. Dept. of 
appliances and reported that the lateral incisor attached to the archwire with an elastomeric ring exhibited a greater number of microorganisms in the plaque than teeth ligated with steel wire. They also reported a significant increase in the number of S. mutans and lactobacilli in the saliva after the insertion of fixed appliances. They recommended that the use of elastomeric ligation rings should be avoided in patients with inadequate oral hygiene because elastomeric ligation rings will significantly increase microbial accumulation on tooth surfaces adjacent to the brackets, leading to a predisposition for the development of dental caries and gingivitis.

More than 600 bacterial species comprise the plaque microflora that exists on surfaces within the oral cavity. ${ }^{13}$ Caries-related bacteria, including Streptococcus mutans and Lactobacillus, ${ }^{14}$ and periodontitis-associated bacteria, such as Eubacterium, Fusobacterium, and Treponema, ${ }^{15}$ have been detected in orthodontic appliance-associated dental plaque.

Triclosan, a chlorophenol derivative, kill germs by interfering with the enzymes required for fatty acid synthesis. Similar to triclosan the fluorinated products were also found to possess marked antibacterial activities. These active compounds were reducing cariogenic bacteria to strengthen the teeth by reducing demineralization and increasing remineralization of teeth. ${ }^{16}$

To date, there is no comprehensive studies have been carried out in Bangladesh to compare the bacterial level of dental plaque in subjects with or without fixed orthodontic appliance. Therefore the aim of the study was to determine the level of bacteria in dental plaque associated with fixed orthodontic appliances.

\section{MATERIALS AND METHODS}

100 patients were selected purposively who are selected for fixed orthodontic treatment. Subjects age should have 11 to 25 years, no history of previous orthodontic treatment, Presence of all teeth except 3rd molars. Patient should co-operative and should have healthy periodontium. Subjects who have severe crowding were excluded from the study.

According to selection criteria 100 subjects were selected purposively. At the beginning and 3 months after orthodontic treatment of each subject, plaque was collected with sterile probe from 1st molars and or premolars and transferred to sterile test tube containing $5 \mathrm{ml}$ of normal saline. Samples were stored in cold place and transported to the Laboratory.

Score Criteria for Plaque

0 No plaque

1 A film of plaque adhering to the free gingival margin and adjacent area of the tooth, which cannot be seen with the naked eye. But only by using probe

2 Moderate accumulation of deposits within the gingival pocket, on the gingival margin and/ or adjacent tooth surface, which can be seen with the naked eye

3 Abundance of soft matter within the gingival pocket and/or on the tooth and gingival margin.

One hundred micro liter of undiluted samples were collected with micro pipette and spread on the surface of Plate count -agar media using sterile spreader. Cultures were incubated anaerobically for $24 \mathrm{hrs}$ at $37^{\circ} \mathrm{C}$. Count of more than 20 colonies were considered as positive samples.

After estimation of positive samples on the surface of plate count-agar medium, small colonies were subcultured on the surface of blood-agar plates for further purification and incubated anaerobically for 24 hours at $37^{\circ} \mathrm{C}$. The following methods were used for initial characterization of the isolates:

1. Colonial shape and form on plate count-agar and blood agar.

2.Gram-staining and microscopic examination

3.Biochemical test

a.Voges- Proskauer (VP) test b.Methyl Red (MR) test

4.Antibiotic sensitivity

At first prepare a Muller Hilton Broth, then inoculated colonies and incubate for 6 hours at $37^{\circ} \mathrm{C}$. Then collected the sample from broth with sterile swab stick and spread to Muller Hilton agar plate. In the plate hole was prepared on the centre of the plate for control point and on the periphery for different antibiotics. In control point hole filled with sterile water and peripheral hole filled with different antibiotics ( 10 times diluted) and incubated for 24 hours at $37^{\circ} \mathrm{C}$.

Antibiotic used in this study: Amoxicilline, Cephradine, Cefuroxime, Cefixime, Doxicycline, Clindamycine, Metronidazol, Flucloxacilline, Ciprofloxacin, Arithromycin, Amoxiciline + clavulanic acid

5.Mouth wash and paste sensitivity

Mouth wash was diluted with same amount of water (1:1) and $1 \mathrm{gm}$ paste was mixed with $1 \mathrm{ml}$ of water. a Muller Hilton Broth was prepared then inoculated colonies and incubated for 6 hours at $37^{\circ} \mathrm{C}$. Then collected the sample from broth with sterile swab stick and spread to Muller Hilton agar plate. In the plate hole was prepared on the centre of the plate for control point and on the periphery for different paste and mouth wash. In control point hole filled with sterile water and peripheral hole filled with different antibiotics (10 times diluted) and incubated for 24 hours at $37^{\circ} \mathrm{C}$.

Mouth wash used in this study: Arodine, Oroclean

Paste used in this study: Pepsodent Gum care, Pepsodent Sensitive, Pepsodent Germy check, Meryl Baby gel, Darlie baby gel, Paradontex, Sensodyne, Close up 


\section{MiCROBIOLOGICAL ANALYSIS}

\begin{tabular}{|c|c|c|c|c|c|c|c|c|}
\hline \multirow[t]{2}{*}{ Pt Name } & \multicolumn{3}{|c|}{ Gram staining } & \multirow{2}{*}{$\begin{array}{l}\text { Methyle Red } \\
\text { test (MR) }\end{array}$} & \multirow{2}{*}{$\begin{array}{l}\text { VP } \\
\text { test }\end{array}$} & \multirow{2}{*}{$\begin{array}{l}\text { MSA } \\
\text { Media }\end{array}$} & \multirow{2}{*}{$\begin{array}{l}\text { Blood agar } \\
\text { Media }\end{array}$} & \multirow{2}{*}{$\begin{array}{l}\text { Tentative } \\
\text { Microorganism }\end{array}$} \\
\hline & Shape & Arrangment & $\begin{array}{l}\text { Gram } \\
\text { reaction }\end{array}$ & & & & & \\
\hline Afsana 1 & Cocci & Single & Gram+ve & ND & & + & - & Streptococcus \\
\hline Afsana 2 & Cocci & Cluster & Gram +ve & - & - & & $\begin{array}{l}+ \\
\alpha \text {-hemolysis }\end{array}$ & Stapleylococcuus \\
\hline Afsana 3 & Large rod & Chain & Gram +ve & - & - & + & $\begin{array}{l}+ \\
\beta \text {-hemolysis }\end{array}$ & Streptococcus \\
\hline Riya 1 & Cocci & Chain & Gram +ve & ND & ND & _ & $\begin{array}{l}+ \\
\alpha \text {-hemolysis }\end{array}$ & Streptococcus \\
\hline Riya 2 & Cocci & Chain & Gram +ve & ND & ND & + & _- & Streptococcus \\
\hline Riya 3 & Rod & Single & Gram +ve & - & - & + & - & Streptococcus \\
\hline Rozy 1 & Rod & Single & Gram+ve & + & - & - & - & Streptococcus \\
\hline Rozy 2 & cocci & Cluster & Gram +ve & + & - & + & _- & Stapltylococcuus \\
\hline Rozy 3 & Cocci & Cluster & Gram+ve & ND & ND & - & $\begin{array}{l}+ \\
\alpha \text {-hemolysis }\end{array}$ & Staphylococcuuts \\
\hline Rumi 1 & Cocci & Single & Gram +ve & ND & ND & - & $\begin{array}{l}+ \\
\alpha \text {-hemolysis }\end{array}$ & Streptococcus \\
\hline Rumi 2 & Diplococci & Diploid & Gram +ve & + & - & - & - & Streptococcus \\
\hline Mou 1 & Cocci & Single & Gram +ve & + & - & - & - & Streptococcus \\
\hline Mou 2 & Cocci & Cluster & Gram +ve & ND & ND & - & $\begin{array}{l}+ \\
\alpha \text {-hemolysis }\end{array}$ & Staplyylococcuus \\
\hline Shimu 1 & Rod & Single/Chain & Gram +ve & ND & ND & - & - & Streptococcus \\
\hline Shimu 2 & Rod & single & Gram+ve & + & - & - & - & Streptococcus \\
\hline Nabila & Rod & chain & Gram +ve & + & - & - & - & Streptococcus \\
\hline
\end{tabular}

Table: 1Shows Most of the bacteria are Streptococcus and some are staphylococcus.

Figure: 3. Alfa Hemolysis on Blood Agar Media
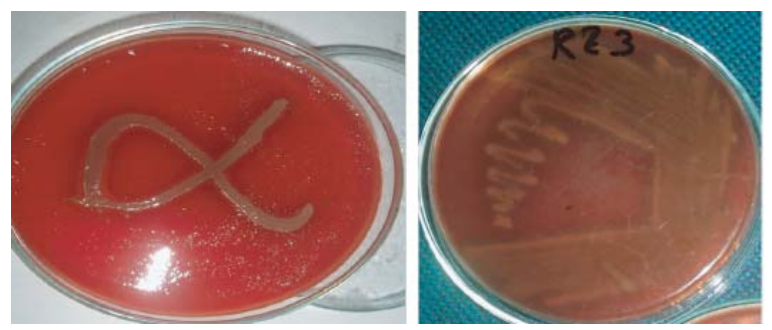

Figure 3 Shows Greenish Alfa hemolytic Zone
Figure: 4. Beta Hemolysis
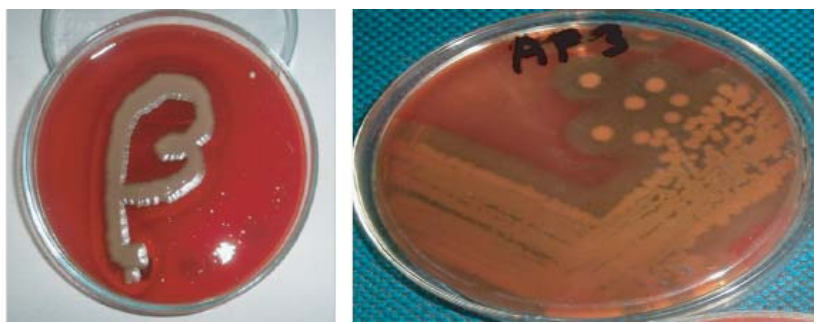

Figure: 4 Shows Clear Beta hemolytic zone 


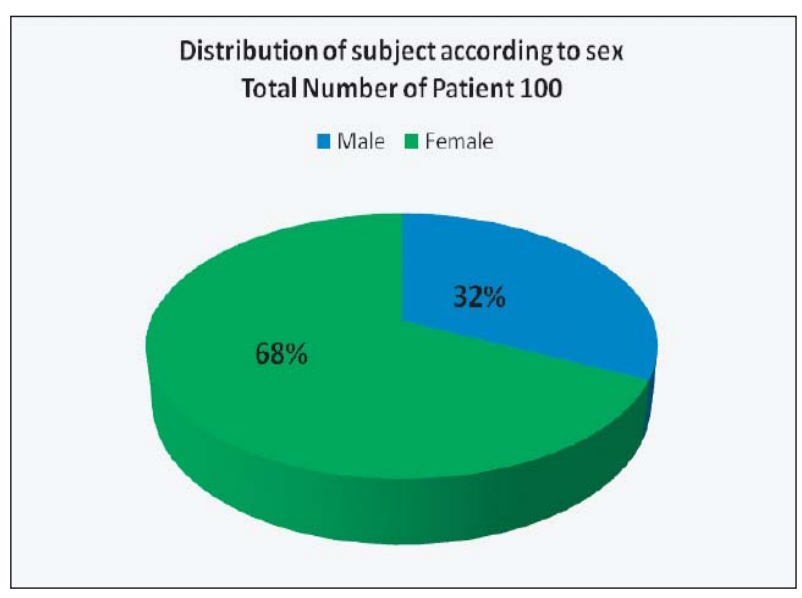

Fegure-5 Number of the patient : Pie chart shows $68 \%$ subjects are female and $32 \%$ are male

Fegure-6 Age wise distribution of Subjects

Total $100(18.38+4.06$ years $) \quad$ Male $32(18.97+4.42$ years $)$

Female $68(18.17+3.89)$

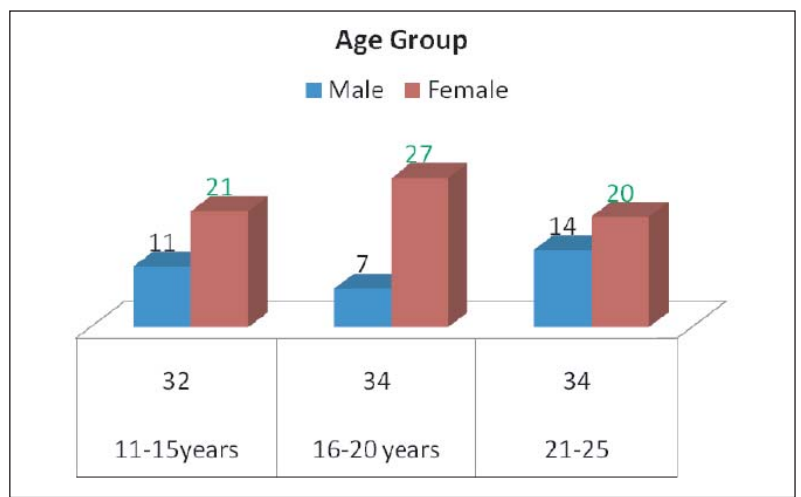

Figure shows all age group carry more or less equal subjects, Female subjects are more in all age group but most in 16-20 years age group.

Table: 2. Brushing habit of male and female according to age group.

\begin{tabular}{|c|c|c|c|c|c|c|}
\hline \multirow[b]{2}{*}{ Sex } & & & \multicolumn{3}{|c|}{ Age group } & \multirow[b]{2}{*}{ Total } \\
\hline & & & 11-15 years & $16-20$ years & $21-25$ years & \\
\hline \multirow[t]{3}{*}{ Male } & Brushing & Once daily & 10 & 2 & 10 & $22(68.75 \%)$ \\
\hline & & Twice daily & 1 & 5 & 4 & $10(31.25 \%)$ \\
\hline & Total & & 11 & 7 & 14 & $32(100 \%)$ \\
\hline \multirow[t]{3}{*}{ Female } & Brushing & Once daily & 19 & 24 & 19 & $62(91.18 \%)$ \\
\hline & & Twice daily & 2 & 3 & 1 & $6(8.82 \%)$ \\
\hline & Total & & 21 & 27 & 20 & $68(100 \%)$ \\
\hline
\end{tabular}

Table: 2 . shows $68.75 \%$ Male subjects brush their teeth once daily and $31.25 \%$ Male subjects brush their teeth twice daily, 16-20 years age group male subjects brushes their teeth comparatively more. 0n the other hand $91.18 \%$ Female subjects brush their teeth once daily. Only $8.82 \%$ female subjects brush their teeth twice daily, comparative less than male $(31.25 \%)$.
Table: 3 . Use of mouthwash by the subjects according to age group

\begin{tabular}{|c|c|c|c|c|c|c|}
\hline \multirow[b]{2}{*}{ Sex } & & & \multicolumn{3}{|c|}{ Age group } & \multirow[b]{2}{*}{ Total } \\
\hline & & & $11-15$ years & $16-20$ years & $21-25$ years & \\
\hline \multirow[t]{3}{*}{ Male } & Mouthwash & Do Not use Mouth wash & 9 & 6 & 11 & $26(81.25 \%)$ \\
\hline & & Use Mouthwash & 2 & 1 & 3 & $6(18.75 \%)$ \\
\hline & Total & & 11 & 7 & 14 & $32(100 \%)$ \\
\hline \multirow[t]{3}{*}{ Female } & Mouthwash & Do Not use Mouth wash & 19 & 25 & 18 & $62(91.18 \%)$ \\
\hline & & Use Mouthwash & 2 & 2 & 2 & $6(8.82 \%)$ \\
\hline & Total & & 21 & 27 & 20 & $68(100 \%)$ \\
\hline
\end{tabular}

Table: 3. shows $18.75 \%$ Male subjects use mouthwash and $81.25 \%$ Male subjects do not use mouthwash. 0n the other hand $91.18 \%$ Female subjects do not use mouthwash. Only $8.82 \%$ female subjects use mouthwash, comparative less than male (18.75\%).

Table : 4. Plaque Index - Before Orthodontic Treatment (PLI A) and During Orthodontic treatment (PLI B) relation with Sex

\begin{tabular}{|c|c|c|c|c|c|c|}
\hline \multirow[t]{2}{*}{ Subjects } & \multicolumn{4}{|c|}{ Mean } & \multirow[t]{2}{*}{$t$} & \multirow[t]{2}{*}{ P value } \\
\hline & $\begin{array}{c}\text { PLI } \\
\text { B }\end{array}$ & PLI A & Difference & Std. Deviation & & \\
\hline Male & 1.97 & 1.31 & 0.66 & 0.82 & 7.236 & .000 \\
\hline Female & 1.62 & 1.12 & 0.40 & 0.73 & 5.073 & .000 \\
\hline Total & 1.73 & 1.18 & 0.55 & 0.78 & 7.021 & .000 \\
\hline
\end{tabular}

Table:4. Shows plaque accumulation significantly increases during orthodontic treatment. Plaque accumulation more in male than female in both group.

Table:5. Effects of Tooth Brush on Plaque accumulation

\begin{tabular}{lcccccc}
\hline & \multicolumn{2}{c}{ PLI A } & \multicolumn{2}{c}{ PLI B } & \multicolumn{2}{c}{ Total Subjects } \\
\cline { 2 - 7 } Brushing & Once daily & Twice daily & Once daily & Twice daily & Once daily & Twice daily \\
Male & 1.45 & 1 & 2.09 & 1.7 & 22 & 10 \\
Female & 1.23 & 1 & 1.73 & 1.67 & 62 & 6 \\
Total & 1.29 & 1 & 1.82 & 1.69 & 84 & 16 \\
\hline
\end{tabular}

Table : 5. shows Plaque accumulation (Plaque Index) less who brush their teeth twice daily in both before and during orthodontic treatment group.

Table:6. Effects of Mouth wash on Plaque accumulation

\begin{tabular}{lcccccc}
\hline \multirow{2}{*}{ Mouthwash } & \multicolumn{2}{c}{ PLI A } & \multicolumn{2}{c}{ PLI B } & \multicolumn{2}{c}{ Total Subjects } \\
\cline { 2 - 7 } Male & Yes & No & Yes & No & Yes & No \\
Female & 1.17 & 1.35 & 1.67 & 2.04 & 26 & 6 \\
Total & 1.17 & 1.11 & 1.47 & 1.56 & 62 & 6 \\
\hline
\end{tabular}

Table: 6. shows Plaque Index (PLI) less who use mouth wash in both before (PLI A) and after treatment group (PLI B) except female subjects of before treatment group.

Table: 7. Bacterial Count - CFU/mg (Before Orthodontic TreatmentCFU 1 and During Orthodontic treatment - CFU2)

\begin{tabular}{|c|c|c|c|c|c|c|}
\hline \multirow[t]{2}{*}{ Subjects } & \multicolumn{4}{|c|}{ Mean } & \multirow[t]{2}{*}{$t$} & \multirow{2}{*}{$\begin{array}{c}P \\
\text { value }\end{array}$} \\
\hline & $\overline{\mathrm{CFU}} 2$ & CFU 1 & Difference & Std. Deviation & & \\
\hline Male & $1.85 \times 10^{5}$ & $1.16 \times 10^{5}$ & $0.69 \times 10^{5}$ & $1.03 \times 10^{5}$ & 3.831 & .001 \\
\hline Female & $1.11 \times 10^{5}$ & $0.87 \times 10^{5}$ & $0.24 \times 10^{5}$ & $0.55 \times 10^{5}$ & 3.639 & .001 \\
\hline Total & $1.35 \times 10^{5}$ & $0.96 \times 10^{5}$ & $0.38 \times 10^{5}$ & $0.76 \times 10^{5}$ & 5.092 & .000 \\
\hline
\end{tabular}

Table: 7. Shows bacterial count significantly increases in during orthodontic treatment group 
Table: 8 Effects of tooth brush on bacterial colonization

\begin{tabular}{|c|c|c|c|c|c|c|c|}
\hline & & $\begin{array}{l}\text { CFU2/gm } \\
\text { (mean) }\end{array}$ & $\begin{array}{l}\text { CFU1/gm } \\
\text { (mean) }\end{array}$ & $\begin{array}{l}\text { Difference } \\
\text { CFU/mg } \\
\text { (Mean) }\end{array}$ & $\begin{array}{l}\text { Std. } \\
\text { Deviation }\end{array}$ & $t$ & P-value \\
\hline \multirow[t]{2}{*}{ Male } & Once daily & $1.70 \times 10^{5}$ & $1.26 \times 10^{5}$ & $0.44 \times 10^{5}$ & $0.83 \times 10^{5}$ & 2.517 & .020 \\
\hline & Twice daily & $1.08 \times 10^{5}$ & $0.94 \times 10^{5}$ & $0.14 \times 10^{5}$ & $1.00 \times 10^{5}$ & .463 & .654 \\
\hline \multirow[t]{2}{*}{ Female } & Once daily & $1.15 \times 10^{5}$ & $0.90 \times 10^{5}$ & $0.25 \times 10^{5}$ & $0.57 \times 10^{5}$ & 3.445 & 001 \\
\hline & Twice daily & $0.68 \times 10^{5}$ & $0.50 \times 10^{5}$ & $0.18 \times 10^{5}$ & $0.32 \times 10^{5}$ & 1.387 & .224 \\
\hline \multirow[t]{2}{*}{ Total } & Once daily & $1.29 \times 10^{5}$ & $0.99 \times 10^{5}$ & $0.30 \times 10^{5}$ & $0.65 \times 10^{5}$ & 4.250 & .000 \\
\hline & Twice daily & $0.94 \times 10^{5}$ & $0.78 \times 10^{5}$ & $0.16 \times 10^{5}$ & $0.79 \times 10^{5}$ & .800 & .346 \\
\hline
\end{tabular}

Table: 8. Shows Bacterial count decreases who brush their teeth twice daily but not significantly.

Table: 9. Effects Mouthwash on Microbial colonization

\begin{tabular}{cccccccc}
\hline & & $\begin{array}{l}\text { CFU2/gm } \\
\text { (mean) }\end{array}$ & $\begin{array}{l}\text { CFU1/gm } \\
\text { (mean) }\end{array}$ & $\begin{array}{l}\text { Difference } \\
\text { CFU/mg } \\
\text { (Mean) }\end{array}$ & Std. Deviation \\
Mouthwash
\end{tabular}

Table : 9. Shows Bacterial count decreases who use mouthwash.

Figure: . Antibiotic sensitivity (Bar Chart)

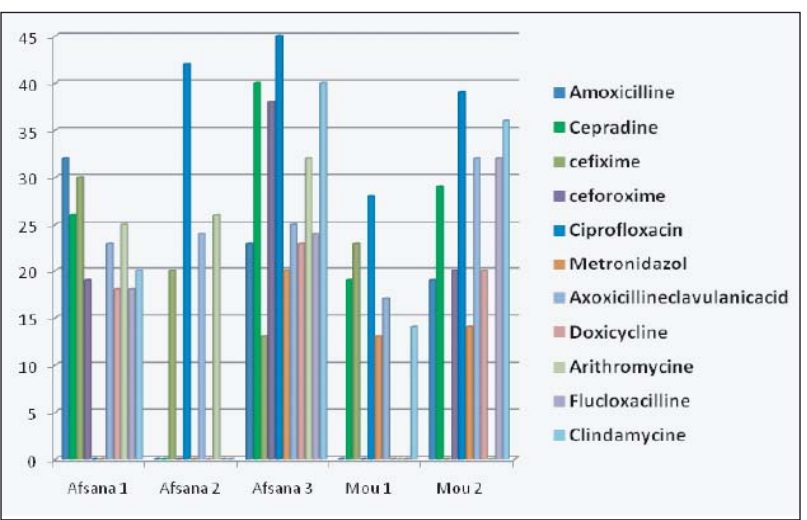

Figure: 15. shows Most of the organism are sensitive to antibiotic. Some bacteria are more sensitive to ciprofluxacine, cephradine, and clindamycine

Figure: Antibiotic sensitivity test

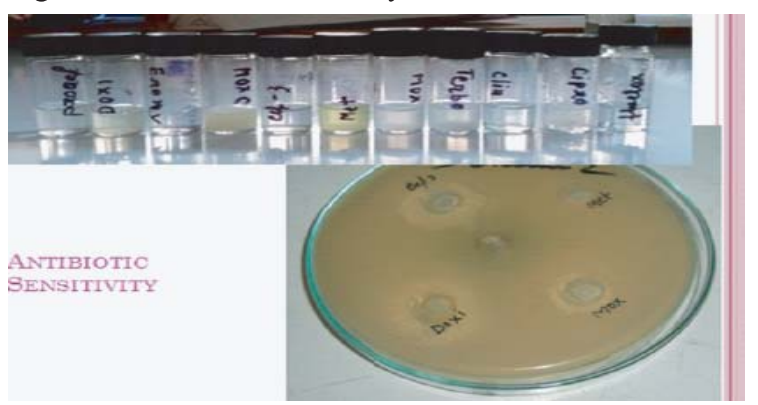

Figure: . shows Bacteria are sensitive to antibiotic
Figure : 17. Mouthwash sensitivity

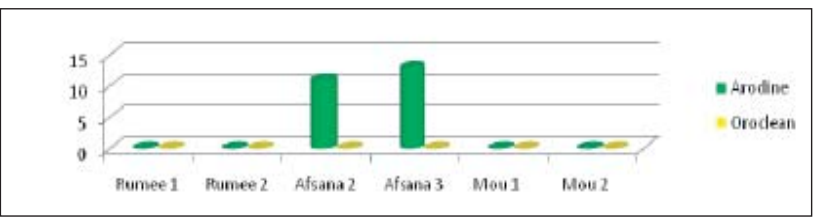

Figure: 17. Shows Most of the bacteria are resistant to mouthwash

Figure: 18. Paste sensitivity

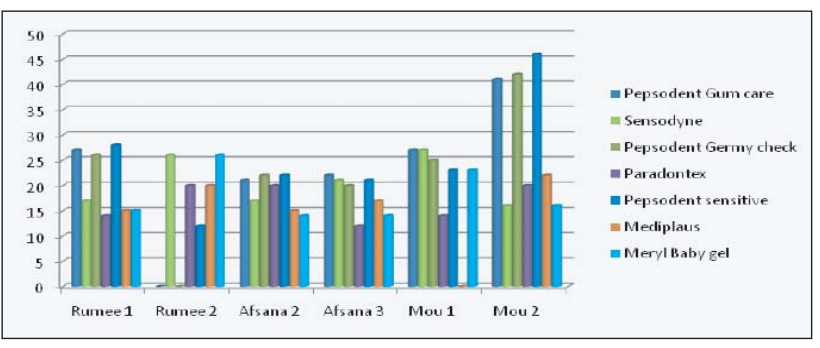

Figure: 18. shows most of the bacteria are sensitive to Paste

Figure: 19. Mouthwash and paste sensitivity

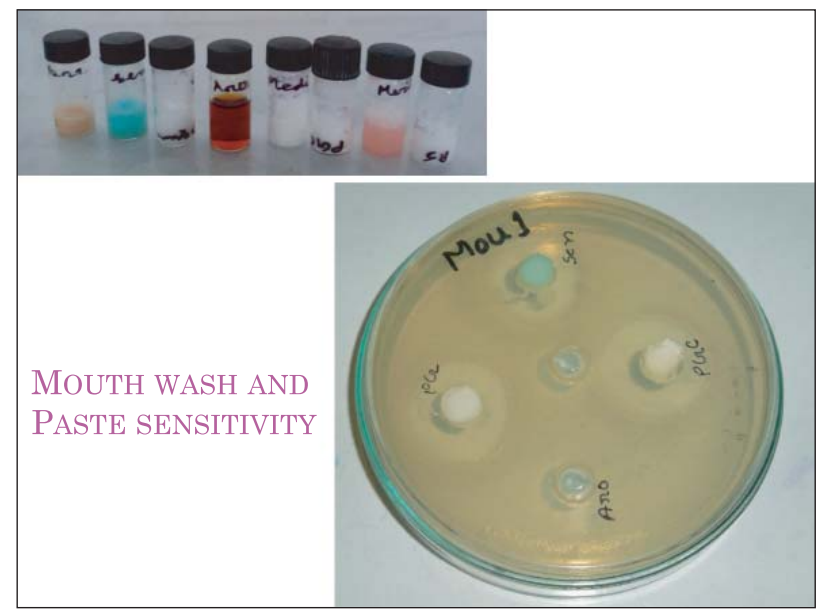

Figure: 19. shows bacteria are sensitive to pate (PG, PGC, Sen) but resistant to mouthwash (Aro).

\section{DISCUSSION}

This study, which investigated microflora before and during fixed orthodontic therapy, indicated that the wearing of fixed orthodontic appliances leads to increased plaque accumulation and significant increased in the oral bacterial colonization, possibly due to the appliances hamper good oral hygiene maintenance and the appliance - introduced ecological alterations within the oral cavity. Before insertion of orthodontic appliance, the plaque Index (PLI A) and the Bacterial count (CFU 1) were measured. Then after insertion of fixed orthodontic appliance, the plaque index (PLI B) and the bacterial count (CFU 2) was measured. Study result 
showed Plaque Index significantly increased after insertion of fixed orthodontic appliance. Before Orthodontic therapy, Plaque Index (PLI A) was 1.18 and after insertion of fixed appliance Plaque Index (PLI B) increased to 1.73. Similar study conducted by U. Hagg et al. ${ }^{17}$ and found a 10 percent mean increase in the plaque index after insertion of Fixed orthodontic appliance. Similar changes in plaque accumulation during orthodontic treatment with removable appliances 18,19 and Fixed orthodontic appliances have been reported by several authors. ${ }^{20,21}$

Scheie et al. also found the similar result and concluded that, the presence of rough surfaced bonding materials acting as a plaque trap may have played a contributory factor. ${ }^{22}$

In contrast to these observation, Sinclair et al. ${ }^{23}$ showed no significant difference in plaque accumulation between pre-treatment and the insertion of Fixed orthodontic appliance. This finding has been supported by Davies et al. ${ }^{24}$ who evaluated the occlusal status, dental health and sociopsychological development. They concluded that, behavioral factors rather than the orthodontic treatment itself were responsible for the additional gain in oral hygiene and gingival health experienced by the patients fitted with orthodontic appliance. However, a survey performed by Kwan ${ }^{25}$ in Hong Kong from lower income groups, demonstrated a significant increase in Plaque index after insertion of a Fixed orthodontic appliance, confirming the earlier hypothesis that in addition to the patient's attitude and behavior, social class may also be a contributory factor in controlling plaque accumulation. Hence the significant increase in the Plaque Index after insertion of fixed orthodontic appliance in present study could partly be due to the patient's attitude and behavior, as well as the presence of Fixed orthodontic appliance which made it difficult to keep the teeth clean.

Possibly as a consequence of the increased plaque index, a concomitant increased bacterial count of 0.38 X 105 $\mathrm{CFU} / \mathrm{mg}$ was noted after insertion of fixed orthodontic appliance in the present study. Similar results were found by U. Hagg , Rosenbloom et al. and Sukuntapatipark et al. ${ }^{26,27}$

This study shows most of the antibiotic and paste were sensitive against bacteria and plaque accumulation decreased who brush their teeth twice daily and who use mouth wash. The treatment with fixed appliance may alter the ecological environment in the oral cavity by introducing new stagnant areas available for bacterial colonization. The appliance may interfere with proper oral hygiene practice. Proper teeth brushing and use of mouth wash can control plaque accumulation as well as bacterial colonization.

\section{CONCLUSION}

Based on the observation of the study, in conclusion followings are suggested:

1. The components of fixed appliance increases the chance of accumulation of plaque as well as Bacterial colonization.

2. Plaque accumulation less who brush their teeth twice daily.

3. Appropriate tooth brush with proper paste can inhibit microbial colonization on tooth surfaces.

References

1. Brusca MI, Chara O, Sterin-Borda L, Rosa AC. Influence of different orthodontic brackets on adherence of microorganisms in vitro. Angle Orthod. 2007;77:331-6.

2. Lee SJ, Kho HS, Lee SW, Jang WS. Experimental salivary pellicles on the surface of orthodontic materials. Am J Orthod Dentofacial Orthop. 2001;119:59-66.

3. Hayder F. Saloom , Harraa S. Mohammed-Salih and Shaymaa F. Rasheed, The influence of different types of fixed orthodontic appliance on the growth and adherence of microorganisms (in vitro study)

4. Batoni G, Pardini M, Giannotti A, Ota F, Giuca MR, Gabriele M, et al. Senesi. Effect of removable orthodontic appliances on oral colonization by mutans streptococci in children. Eur J Oral Sci 2001;109:388-92.

5. Vizitiu, Th. C.; Ionescu, Ecaterina , Microbiological changes in orthodontically treated patients, Therapeutics, Pharmacology \& Clinical Toxicology;2010, Vol. 14 Issue 4, p283

6. Jordan C, LeBlanc DJ. Influences of orthodontic appliances on oral populations of mutans streptococci. Oral Microbiol Immunol 2002;17:65-71.

7. Arends J, Christofferson I. The nature of early caries lesions in enamel. J Dent Res 1986;65:2-11.

8. O'Reilly MM, Featherstone JD. Demineralization and remineralization around orthodontic appliances: An in vivo study. Am J Orthod Dentofacial Orthop 1987;92:33-40.

9. Bhagchandani J, Singh AK, Mehrotra P, Shashi Kumar H C, Varshney SR, Varshney KR. Microbial colonization around orthodontic ligature ties: An in-vivo study. APOS Trends Orthod [serial online] 2013 [cited 2014 Oct 22];3:72-7.

10. Cawson R. A and Odell E. W. Dental Caries. Cawson's Essentials of Oral Pathologyand Oral Medicine. Seventh edition, 2002:38-39.

11. Forsberg CM, Brattström V, Malmberg E, Nord CE. Ligature wires and elastomeric rings: Two methods of ligation, and their association with microbial colonization of Streptococcus mutans and lactobacilli. Eur J Orthod 1991;13:416-20.

12 Chang HS, Walsh LJ, Freer TJ. The effect of orthodontic treatment on salivary flow, pH, buffer capacity, and levels of mutans streptococci and lactobacilli. Aust Orthod J 1999;15:229-34.

13. Kolenbrander PE, Palmer Jr RJ, Periasamy S, Jakubovics NS. Oralmultispecies biofilm development and the key role of cell-cell distance. Nat Rev Microbiol 2010;8:471-80.

14. Sanpei S, Endo T, Shimooka S. Caries risk factors in children under treatment with sectional brackets. AngleOrthod2010;80:509-14. 
15. Kim SH, Choi DS, Jang I, Cha BK, Jost-Brinkmann PG, Song JS .Microbiologic changes in subgingival plaque before and during the early period of orthodontic treatment. Angle Orthod 2012;82:254-60.

16. A. Maripandi, A. T. Kumar and A. A. Al Salamah, "Preva- lence of Dental Caries Bacterial Pathogens and Evalua- tion of Inhibitory Concentration Effect on Different Tooth Pastes against Streptococcus spp.,” African Journal of Microbiology Research, Vol. 5, No. 14, 2011, pp. 1778- 1783.

17. Davies T. M, Shaw W. C, Worthington H. V, Addy M, Dummer P, Kingdon A. The effect of orthodontic treatment on plaque and gingivitis. American Journal of Orthodontics and Dentofacial Orthopedics; 1991; 99:155-161

18. Kwan E. Oral health status of 13 and 15 yeasr-old secondary school children in Hong Kong.Thesis, University of Hong Kong,1992

19. Rosenbloom R. G, Tinanoff N. Salivary streptococcus mutans levels in patients before, during and after orthodontic treatment. American Journal of Orthodontics and Dentofacial Orthopedics;1991; 100:35-37

20. Sukontapatipark W, El-Agroudi M. A, Selliseth N. J, Thanold K and Selvig K. A. Bacterial colonization associated with fixed orthodontic appliances. A scanning electron microscopy study. European Journal of Orthodontics, 2001: 23:475-484.
21. Boyd R. L. Longitudinal evaluation of a system for self monitoring plaque control effectiveness in orthodontic patients. Journal of clinical Periodontology. 1983;10:380-388

22. Scheie A. A, Arneberg P, and Krogstad O. Effects of orthodontic treatment on prevalence of Streptococcus mutans in plaque and saliva. Scandinavian Journal of Dental research, 1984: 92:211-217.

23. Sinclear P. M, Berry C. W, Bennet C. L, Israelson H. Changes in gingival and gingival flora with bonding and banding. Angle Orthodontist, 1987: 57: 271-278.

24. Davies T. M, Shaw W. C, Worthington H. V, Addy M, Dummer P, Kingdon A. The effect of orthodontic treatment on plaque and gingivitis. American Journal of Orthodontics and Dentofacial Orthopedics;1991; 99:155-161

25. Kwan E. Oral health status of 13 and 15 yeasr-old secondary school children in Hong Kong.Thesis, University of Hong Kong,1992

26. Rosenbloom R. G, Tinanoff N. Salivary streptococcus mutans levels in patients before, during and after orthodontic treatment. American Journal of Orthodontics and Dentofacial Orthopedics;1991; 100:35-37

27. Sukontapatipark W, El-Agroudi M. A, Selliseth N. J, Thanold K and Selvig K. A. Bacterial colonization associated with fixed orthodontic appliances. A scanning electron microscopy study. European Journal of Orthodontics, 2001: 23:475-484.

Correspondence

Dr. Kohinoor Sabnam BDS, MSc
Dental surgeon
Mamun's Orthodental
Mob: +88 01712313528
E-mail: kohinoor_mn@yahoo.com

Bangladesh Journal of Orthodontics and Dentofacial Orthopedics (BJO \& DFO) 